\title{
Innovative Ecosphere in Higher Education Institutions: An Exploratory Study
}

\author{
Mohd Faiz Hilmi \\ School of Distance Education \\ Universiti Sains Malaysia \\ 11800, Gelugor, Penang, Malaysia \\ faiz@usm.my
}

\section{Introduction}

Optimization of innovation by higher learning institutions are the main factors in determining the nation's success and well-being. Thus, developing a culture of innovation in higher education institutions among academicians, non-academic staff and students is essential in creating an innovation eco-sphere that supports innovation activities. However, fostering innovative human capital at higher education level is very challenging. In order to encourage the creation and development of a society that embraces a culture of creativity and innovation for the nation's success and well being, there should be a coordinated innovation ecosystem capable of moving the nation towards an innovative society. Through enhanced ecosphere, innovative culture among all academicians, non-academic staff and students will flourish. Malaysia's expectation to be globally competitive within a high-income economy that is innovation-led will depend on the needs to create the "right" innovation ecosystem one that is fully capable of developing and sustaining an innovation charged workforce. Innovative ecosphere in HEIs contributes to value creation and produce solutions to various challenges. It is a complex, dynamic, emergent system that constantly adapts, sometimes in unexpected ways. Strong performance of an innovative ecosphere requires reduction of uncertainty in innovation processes. One way to reduce uncertainty is by optimizing the innovative ecosphere. Optimization of innovative ecosphere in HEIs will maximize value creation benefitting the society at large.

Innovation ecosphere in Malaysian higher education institutions can be developed based on several parameters that act as enablers to its formation. An enabler of building ecosphere innovation is identified through the review of the four major documents: (i) MOHE Implementation Plan For Development of Innovative Human Capital at Tertiary Level, (ii) MQA01 documents for the application to offer new programs (iii) National Innovation Strategy; Innovating Malaysia, Creating Wealth Through Knowledge, Technology and Innovation by the Malaysian Innovation Agency and (iv) USM's Vice-Chancellor's message 
in 2013 "Synergizing Eco-Sphere for Excellence University". Based on the analysis of these document analysis, seven enablers were identified to develop an eco-sphere innovation. The seven enablers are (i) Governance, (ii) Financial Sustainability, (iii) Research and Innovation (iv) Talent (v) Academic (vi) Support and Services and (vii) Positioning. Therefore, this study explores the identifies seven enablers of an innovative environment in Malaysian tertiary education institutions.

\section{Governance}

Effective governance facilitate the achievement of objectives set in the administration. In order to create an environment of innovation in Higher Education Institutions, there should be good governance, development support and innovation environment. Governance is the government's ability to establish and enforce rules, and to deliver services, regardless of whether that government is democratic or not (Fukuyama, 2014). A good and effective administrator should be transparent, accountable, participatory, inclusive and consensus oriented, abide by the rules and laws, responsive, efficient and effective, and high levels of sustainability.

The Malaysian government supported various initiatives related to the innovation-led economy (MAMPU, 2010). The Special Unit for Innovation or Unit Inovasi Khas (UNIK) was established under the Prime Minister's office to act as the focal point for innovation in Malaysia (AIM, 2012). UNIK drives innovation strategies and policies, while Malaysia Innovation Agency or Agensi Inovasi Malaysia (AIM) was established to act as the implementation arm for innovation related initiatives (AIM, 2012).

To ensure good governance conducted are in line with what the government intended, a system of works forming operations "check and balance" should be introduced. At higher education institutions, various systems make up the environment "check and balance" such as the quality assurance unit, accreditation centers, innovation centers, learning and teaching center, integrity center and so on.

\section{Financial Sustainability}

Financial sustainability is vital to any organization. Malaysian government has encouraged all institutions to generate their own income. Therefore, higher education institutions need to review the various expenses incurred at university. Expenses should be carried out prudently 
and profitably. Higher Education Institutions can generate income from a variety of activities with support from all academicians and non-academic staff. Such activities include consultancy, registration of intellectual property, research commercialization, research grants from external agency, entrepreneurial activity and so on. At the same time, the administration should support all activities that benefit the university staff. Adverse bureaucracy and discourage motivation should be eliminated.

It is important for all higher education institutions in Malaysia to prepare towards financial sustainability by seeking alternative sources to increase the financial resources that would eventually create one entity that could reduce the dependence on government funds.

Therefore, it is very important for all higher education institutions in Malaysia to preserve financial management in order to create an environment of innovation in their respective institutions.

\section{Research and Innovation}

Higher Education Institutions in Malaysia should develop research and innovation sector to produce impact on science, technology, an environment and mankind. Furthermore, for Malaysia to develop an innovative human capital in the knowledge-based and innovationcentered economy, Malaysian Higher Education should serve as a reservoir of knowledge. In this respect, the Malaysian public and private universities have to act as organizations that develop a society that is analytic, informative, skilful, creative and innovative and promotes the nation as a centre of academic excellence, while taking the lead in creating new fields of knowledge through research activities (Ismail and Abdullah, 2011).

The environment for research and innovation will become more robust and effective when all the research to be conducted at the university are planned and well-managed. The Ministry of Higher Education aims to create 20 world class international HICoE by the year 2020 to strengthen research and innovation. (MoHE, 2010). The research planning and management unit should play its roles in ensuring that research activities and research management are carried out smoothly and effectively.

Therefore, to create an innovative environment that is sustainable, emphasis on research activities is very important. Finally, research and development activities should benefit all 
communities. An innovation ecosphere will emerge through the culture of research and development activities among members of higher education institutions in Malaysia.

\section{Talent}

Currently there is a rising demand for quality human capital. Therefore, to ensure that higher education institutions in Malaysia are significant and relevant to the current demands and challenges, it is important to create a talent that can produce first-class global citizens.

Higher education institutions in Malaysia should ensure that systems and nurturing talent occur in a professional, transparent and systematic way. Empowerment to all university's citizen should be implemented in a planned and efficient manner (AIM, 2012). Empowerment means that all institutions need to ensure that every academician and non-academic staff are authorized to perform a task and decision, perform their assigned responsibilities with dedication and responsibility, based on the core values, and are willing to accept any effects of action or decisions made. This does not mean that they are giving power to the officers under them and escape from their responsibilities.

\section{Academic}

Education plays a central role in any country's pursuit of economic growth and national development. There is no better predictor of a nation's future than what is currently happening in its classrooms. In today's global economy, a nation's success depends fundamentally on the knowledge, skills and competencies of its people. It is no surprise that nations with higher education levels tend to enjoy greater economic prosperity. Education is also fundamental to nation building and unity. It provides individuals with the opportunity to improve their lives, become successful members of the community and active contributors to national development. Through interacting with individuals from a range of socio-economic, religious and ethnic backgrounds - and learning to understand, accept and embrace differences - a shared set of experiences and aspirations for Malaysia's future can be built. It is through these shared experiences and aspirations that a common national identity and unity is fostered.

Higher education institutions in Malaysia need to produce relevant academic programs, to produce a responsible global citizen. Graduates of higher education institutions in Malaysia should be developed based on the values and knowledge of ecological protection, conservation 
of resources, and human development based on the values of equality, accessibility, availability, suitability, appropriateness and capable of designing a holistic quality life.

\section{Support and Services}

All employees are expected to contribute their services towards generating profit and sharing it with the rest of the departments and institutions. Services can be commercialized to generate income for the university. Services are marketed through a network of strategic and profitable relationships.

In order to ensure higher education in Malaysia always provide good and high quality support and services, the Ministry of Higher Education established the Malaysian Qualifications Agency; a national quality agency that undertakes the implementation of the Malaysian Qualifications Framework, covering both public and private higher educational institutions, accreditation of courses and other related functions. The provision of higher education is currently regulated by the following legislations:

1. The Education Act 1996 (Act 550)

2. The Private Higher Educational Institutions Act, 1996 (amended 2009)

3. The National Council of Higher Education Act, 1996

4. Malaysian Qualifications Agency Act 2007 (replacing the National Accreditation Board Act 1996 which has been repealed)

5. The Universities and University Colleges (Amendment) Act, 1996 (amended 2009

Support and services in government sectors especially in higher education environments is very important in creating innovation ecosphere. Any attempts to build an innovation ecosphere in higher education at Malaysian institutions need strong support from all parties especially in support and services parameter.

\section{Position}

Positioning is important for the reliability and credibility of institution. Higher education institutions need to reposition themselves to a level that is better than the status quo. Higher education institutions need to reposition themselves in order to highlight anything done and produced by the university in order to be known, valued, appreciated and enjoyed by the stakeholders of the university. 


\section{Profile of Respondents}

The respondents comprise of 52.1 per cent female (Table 1). In term of age, majority of the respondents, 38.7 per cent are between 31 to 40 years old. Majority of the respondents, 50.7 per cent, holds Doctor of Philosophy degree and had been working less than 10 years (60.6 per cent). A total of 42.3 per cent of the respondents are senior lecturer with $\mathrm{PhD}$. Respondents attached to six public universities namely UMK, UMS, UPM, USM, UTHM and UTM.

Table 1 Demographics

\begin{tabular}{|c|c|c|}
\hline Items & Frequency & Percentage \\
\hline \multicolumn{3}{|l|}{ Institution } \\
\hline UMK & 40 & 28.2 \\
\hline UMS & 16 & 11.3 \\
\hline UPM & 22 & 15.5 \\
\hline USM & 13 & 9.2 \\
\hline UTHM & 15 & 10.6 \\
\hline UTM & 36 & 25.4 \\
\hline \multicolumn{3}{|l|}{ Designation } \\
\hline Professor & 3 & 2.1 \\
\hline Associate Professor & 16 & 11.3 \\
\hline Senior Lecturer with $\mathrm{PhD}$ & 60 & 42.3 \\
\hline Senior Lecturer without PhD & 4 & 2.8 \\
\hline Lecturer & 47 & 33.1 \\
\hline Tutor & 12 & 8.5 \\
\hline \multicolumn{3}{|l|}{ Highest Academic Qualification } \\
\hline Doctor of Philosophy & 72 & 50.7 \\
\hline Master & 47 & 33.1 \\
\hline Bachelor & 7 & 4.9 \\
\hline \multicolumn{3}{|l|}{ Year of Service } \\
\hline $1-10$ & 86 & 60.6 \\
\hline $11-20$ & 32 & 22.5 \\
\hline $21-30$ & 9 & 6.3 \\
\hline $31-40$ & 6 & 4.2 \\
\hline \multicolumn{3}{|l|}{ Age } \\
\hline$<30$ & 29 & 20.4 \\
\hline $31-40$ & 55 & 38.7 \\
\hline $41-50$ & 37 & 26.1 \\
\hline $51-60$ & 20 & 14.1 \\
\hline$>60$ & 1 & 0.7 \\
\hline \multicolumn{3}{|l|}{ Gender } \\
\hline Male & 67 & 47.2 \\
\hline Female & 74 & 52.1 \\
\hline
\end{tabular}




\section{The Outcomes}

Analyses are divided into four sections: reliability, descriptive - variable level, descriptive item level and associational. All of these analyses were based on responses from academics who took part in this study.

\section{Reliability analysis}

Cronbach's Alphas were calculated for all the seven scales used in this study. The value of Cronbach's Alpha for each scale is listed in Table 2. Cronbach's Alphas were at least 0.733 for all the scales reflecting acceptable reliability for the scales.

Table 2 Composite Reliabilities

\begin{tabular}{lccc}
\hline Factor Label & $\begin{array}{c}\text { \# of Items in } \\
\text { Composite }\end{array}$ & $\begin{array}{c}\text { Item } \\
\text { Deleted }\end{array}$ & $\begin{array}{c}\text { Reliability } \\
\text { (Cronbach's } \alpha)\end{array}$ \\
\hline Talent & 7 & - & .864 \\
Support and Services & 19 & - & .933 \\
Academic & 15 & - & .903 \\
Governance & 6 & 1 & .733 \\
Financial Sustainability & 6 & - & .831 \\
Research and Innovation & 4 & - & .830 \\
Institutional Positioning & 5 & - & .848 \\
\hline
\end{tabular}

\section{Descriptive Analysis - Variable Level}

Overall, respondents rated above average for all the variables in this study. Table 3 presented the mean and standard deviation for each variables. Subsequent section explain the descriptive values at the item level.

Table 3 Descriptive Statistics

\begin{tabular}{lcc}
\hline \multicolumn{1}{c}{ Variable } & Mean & Standard Deviation \\
\hline Talent & 3.2765 & .44163 \\
Support and Services & 2.8140 & .49165 \\
Academic & 3.0089 & .43818 \\
Governance & 2.9439 & .49684 \\
Financial Sustainability & 2.7200 & .51366
\end{tabular}




\section{Descriptive Analysis - Item Level}

For the variable talent, all items had a mean of more than three. The lowest mean was for item TA3 whilst the highest was for item TA6. It showed that respondents agreed that they have the talent to be innovative. All items had a standard deviation of less than one.

Table 4 Means and Standard Deviations for Items Measuring Talent

\begin{tabular}{llcc}
\hline Item & & Mean & Std. Deviation \\
\hline TA1 & I am able to adapt to any kind of changes happened & 3.28 & 0.537 \\
TA2 & I have an understanding of good innovation culture & 3.21 & 0.606 \\
TA3 & I have a good level of collaboration to innovate & 3.14 & 0.637 \\
TA4 & I am interested in seeking various knowledge related to & 3.4 & 0.621 \\
& innovation & 3.23 & 0.604 \\
TA5 & I am able to generate knowledge for innovation & 3.47 & 0.542 \\
TA6 & I am willing to share knowledge for innovation & 3.21 & 0.609 \\
\hline
\end{tabular}

Respondents rated support and services above average with mean for all items of more than 2.5 with the lowest for item SS19 and highest for item SS12. It showed that respondents agreed that the support and services provided by their university improve or promote the culture of innovation. All items had a standard deviation of less than one.

Table 5 Means and Standard Deviations for Items Measuring Support and Services

\begin{tabular}{clcc}
\hline Item & \multicolumn{1}{c}{ Mean } & Std. Deviation \\
\hline SS8 & $\begin{array}{l}\text { The infrastructure and facilities provided by the university } \\
\text { promote the culture of innovation amongst students. }\end{array}$ & 2.64 & 0.732 \\
SS9 & $\begin{array}{l}\text { The infrastructure and facilities provided by the university } \\
\text { promote the activities of research }\end{array}$ & 2.74 & 0.753 \\
SS10 & $\begin{array}{l}\text { The infrastructure and facilities provided by the university } \\
\text { promote the culture of innovation amongst lecturers }\end{array}$ & 2.71 & 0.732 \\
SS11 & $\begin{array}{l}\text { Promotion criteria in this university takes into account the } \\
\text { contribution to innovation. }\end{array}$ & 2.92 & 0.747 \\
SS12 & $\begin{array}{l}\text { University established the centre for innovation and } \\
\text { commercialisation to assist and create more innovative } \\
\text { entrepreneurial activities. }\end{array}$ & 3.11 & 0.662 \\
SS13 & $\begin{array}{l}\text { University established the centre for student innovation to } \\
\text { encourage innovation amongst students }\end{array}$ & 2.86 & 0.741
\end{tabular}




\begin{tabular}{|c|c|c|c|}
\hline SS14 & $\begin{array}{l}\text { University conducts various competitions and exhibitions } \\
\text { as platforms to highlight }\end{array}$ & 3.08 & 0.729 \\
\hline SS15 & University provides special grants to encourage innovation & 3.09 & 0.673 \\
\hline SS16 & $\begin{array}{l}\text { The university offers various incentives to encourage } \\
\text { culture of innovation amongst students }\end{array}$ & 2.76 & 0.706 \\
\hline SS17 & $\begin{array}{l}\text { The university offers various incentives to encourage } \\
\text { culture of innovation amongst lecturers }\end{array}$ & 2.77 & 0.769 \\
\hline SS18 & $\begin{array}{l}\text { The university working environment encourages a culture } \\
\text { of innovation amongst lecturers }\end{array}$ & 2.6 & 0.763 \\
\hline SS19 & $\begin{array}{l}\text { The university learning environment encourages a culture } \\
\text { of innovation amongst students }\end{array}$ & 2.59 & 0.716 \\
\hline SS20 & $\begin{array}{l}\text { The university management system assists the lecturers to } \\
\text { get research grants }\end{array}$ & 2.85 & 0.677 \\
\hline $\mathrm{SS} 21$ & $\begin{array}{l}\text { The university management system helps to commercialize } \\
\text { the products of innovation }\end{array}$ & 2.81 & 0.765 \\
\hline $\mathrm{SS} 22$ & $\begin{array}{l}\text { The university management system helps to disseminate } \\
\text { the results of the research }\end{array}$ & 2.76 & 0.689 \\
\hline $\mathrm{SS} 23$ & $\begin{array}{l}\text { The university management system helps to establish } \\
\text { university-industry linkages }\end{array}$ & 2.84 & 0.735 \\
\hline $\mathrm{SS} 24$ & $\begin{array}{l}\text { The university management system helps to establish } \\
\text { collaborative relationships with society }\end{array}$ & 2.84 & 0.735 \\
\hline $\mathrm{SS} 25$ & $\begin{array}{l}\text { University management system assists to establish } \\
\text { relationships with the research community }\end{array}$ & 2.85 & 0.678 \\
\hline SS26 & $\begin{array}{l}\text { University management system assists to establish } \\
\text { relationships with stakeholders. }\end{array}$ & 2.71 & 0.744 \\
\hline
\end{tabular}

Items for variable academic were rated above average with the lowest mean was for item

AC32 and the highest mean was for item AC27. Respondents as academic rated themselves as supportive of innovation agenda. All items had a standard deviation of less than one.

Table 6 Means and Standard Deviations for Items Measuring Academic

\begin{tabular}{|c|c|c|c|}
\hline Item & & Mean & $\begin{array}{c}\text { Std. } \\
\text { Deviation }\end{array}$ \\
\hline $\mathrm{AC} 27$ & $\begin{array}{l}\text { I encourage students to think of new creative ideas in } \\
\text { their respective fields and turn them into solutions that } \\
\text { are useful and have commercial values }\end{array}$ & 3.3 & 0.654 \\
\hline AC28 & $\begin{array}{l}\text { Course delivery approach encourages culture of } \\
\text { innovation among students. }\end{array}$ & 3.01 & 0.631 \\
\hline AC29 & $\begin{array}{l}\text { Course learning outcomes emphasize the creation of } \\
\text { novel ideas which are useful and have commercial values }\end{array}$ & 2.89 & 0.729 \\
\hline AC30 & $\begin{array}{l}\text { Evaluation of teaching and learning emphasizes on a } \\
\text { coherent education experience namely self-monitor, } \\
\text { rehearse, practice and receive feedback }\end{array}$ & 3.07 & 0.666 \\
\hline AC31 & $\begin{array}{l}\text { The university has a special body to monitor the quality } \\
\text { of teaching and learning }\end{array}$ & 3.09 & 0.78 \\
\hline
\end{tabular}


AC32 The current curriculum have been successful in producing innovative graduates.

AC33

I use various teaching approaches to promote innovative culture amongst students

I take into account elements of innovation when assessing students' work. There are specific courses offered to develop innovative

AC35 thinking skills of students

AC36 Content of the courses offered in line with the national innovation policy and agenda The university programs available offer courses leading to the development of creative and innovative skills There are programs that encourage innovation among

AC38 students. innovation There are various incentives available for students to be involved in activities related to innovation

AC41 There are various incentives available for lecturers to be involved in activities related to innovation

Items for variable governance were also rated above average with the lowest item GV47 and the highest item GV42. The respondents agreed that the governance is conducive towards research and innovation. All items had a standard deviation of less than one.

Table 7 Means and Standard Deviations for Items Measuring Governance

\begin{tabular}{clcc}
\hline Item & & Mean & Std. Deviation \\
\hline GV42 & $\begin{array}{l}\text { I freely explore any innovative ideas for research } \\
\text { purposes. }\end{array}$ & 3.21 & 0.585 \\
GV43 & $\begin{array}{l}\text { There is no restriction information needed to perform } \\
\text { research }\end{array}$ & 3.02 & 0.704 \\
GV44 & $\begin{array}{l}\text { Research findings are not subjected to any parties } \\
\text { I am given the freedom to manage my own research } \\
\text { grants. }\end{array}$ & 2.92 & 0.736 \\
GV47 & $\begin{array}{l}\text { Grant management regulation facilitates the innovation } \\
\text { process }\end{array}$ & 2.74 & 0.783 \\
\hline
\end{tabular}

Note: GV45 deleted to improve reliability

Similarly, items for variable financial stability were rated above average with the lowest item FS53 and highest item FS51. The respondent agreed that there are sufficient financial support for innovation. All items had a standard deviation of less than one.

Table 8 Means and Standard Deviations for Items Measuring Financial Stability 


\begin{tabular}{clcc}
\hline Item & \multicolumn{1}{c}{ Mean } & Std. Deviation \\
\hline FS48 & $\begin{array}{l}\text { There are various financial resources available to support } \\
\text { activities related to innovation. }\end{array}$ & 2.78 & 0.668 \\
FS49 & $\begin{array}{l}\text { There are sufficient financial provisions to carry out } \\
\text { activities related to innovation }\end{array}$ & 2.55 & 0.683 \\
FS50 & $\begin{array}{l}\text { There are ongoing funds to continue activities related to } \\
\text { innovation }\end{array}$ & 2.65 & 0.721 \\
FS51 & $\begin{array}{l}\text { The university encourages innovation which leads to } \\
\text { commercialization }\end{array}$ & 3.04 & 0.624 \\
FS52 & $\begin{array}{l}\text { Innovation in this university gives monetary returns to the } \\
\text { researchers }\end{array}$ & 2.73 & 0.668 \\
FS53 & $\begin{array}{l}\text { I contribute to the generation of university revenue through } \\
\text { my innovations }\end{array}$ & 2.51 & 0.758 \\
\hline
\end{tabular}

All items for variable researsh \& innovation were rated above three with the lowest item

RI54 and the highest item RI55. These rating reflect the respondent agreement that they participated in innovative research with impact to the society. All items had a standard deviation of less than one.

Table 9 Means and Standard Deviations for Items Measuring Research and Innovation

\begin{tabular}{clcc}
\hline Item & \multicolumn{1}{c}{ Mean } & Std. Deviation \\
\hline RI54 & $\begin{array}{l}\text { As a researcher, I ensure that my research are innovative } \\
\text { and high impact }\end{array}$ & 3.19 & 0.583 \\
RI55 & $\begin{array}{l}\text { Research planned must have significant impact to the } \\
\text { society }\end{array}$ & 3.42 & 0.586 \\
RI56 & $\begin{array}{l}\text { Research conducted take into account the needs of the } \\
\text { industry } \\
\text { RI57 }\end{array}$ & 3.27 & 0.694 \\
The findings of the study are widely disseminated to ensure & 3.4 & 0.62 \\
\hline
\end{tabular}

Items for variable institutional positioning were rated above average with the lowest item IP59 and the highest item IP58 and IP62. The rating reflect that the respondents believed that their institution is in proper position in supporting innovation related activities. All items had a standard deviation of less than one.

Table 10 Means and Standard Deviations for Items Measuring Institutional Positioning

\begin{tabular}{clcc}
\hline Item & & Mean & Std. Deviation \\
\hline IP58 & $\begin{array}{l}\text { The university is constantly enhancing collaborative } \\
\text { partnership with other universities or organizations to carry } \\
\text { out activities related to innovation. }\end{array}$ & 3.15 & 0.701
\end{tabular}


IP59 The university constantly championed marginalized issues.

IP60 The university is constantly thinking innovative ways to address problems of low society innovative products

\section{Associational analysis}

All variable in this study showed a significant correlation with each other (Table 11). Support and services showed a high correlation with financial sustainability and institutional positing. Furthermore, support and services showed a moderate correlation with academic, governance and research and innovation. In addition to that, financial positioning also had a high correlation with institutional positioning. Talent had a moderate correlation with all other variables except support and services. Overall, the strongest correlation is between support and services and institutional positioning while the weakest correlation is between talent and support and services.

Table 11 Correlation Matrix

\begin{tabular}{lllllllll}
\hline & & 1 & 2 & 3 & 4 & 5 & 6 & 7 \\
\hline 1 & Talent & 1 & & & & & & \\
2 & Support and Services & $.190^{*}$ & 1 & & & & & \\
3 & Academic & $.481^{* *}$ & $.515^{* *}$ & 1 & & & & \\
4 & Governance & $.423^{* *}$ & $.398^{* *}$ & $.365^{* *}$ & 1 & & & \\
5 & Financial Sustainability & $.203^{*}$ & $.655^{* *}$ & $.360^{* *}$ & $.510^{* *}$ & 1 & & \\
6 & Research and Innovation & $.570^{* *}$ & $.224^{* *}$ & $.403^{* *}$ & $.362^{* *}$ & $.206^{*}$ & 1 & \\
7 & Institutional Positioning & $.254^{* *}$ & $.668^{* *}$ & $.471^{* *}$ & $.543^{* *}$ & $.638^{* *}$ & $.283^{* *}$ & 1 \\
\hline
\end{tabular}

$* \rho<0.05 ; * * \rho<0.01$

\section{Conclusion}

The development of innovative human capital has become the National Mission as stated in The 10th Malaysia Plan (2011-2015) and the New Economic Model (NEM) which both stress human capital development and improvements in innovation capacity (Nor Fatimah, 2013). This research findings revealed the four ways to enable innovation embedded in the curriculum to the development of innovative human capital, which are (i) understanding of innovative 
human capital characteristics, (ii) understanding the factors that influence the development of innovative human capital; (iii) implementation in the realization of innovative human capital development and (iv) evaluation of the challenges and obstacles in the implementation of innovative human capital development.

Financial resources and facilities of an institution also can affect the development of innovative human capital. These factor included research facilities, financial resources and facilities provided by an institution. By having a complete and great facilities, research facilities and financial resources will help the institutional residents to develop the innovative culture. Cultural and leadership support also are necessary for the continuity of innovative human capital development. This support included freedom of speech so that every individual in a community institution can voice out their ideas. In addition, senior, administration and leader support of an institution can encourage the staffs to do better work and fully understand the important of excellent and innovation.

\section{References}

Agensi Inovasi Malaysia (2012). National Innovation Strategy Innovating Malaysia; Creating Wealth through Knowledge, Technology and Innovation. Putrajaya, Malaysia: Agensi Inovasi Malaysia.

Francis Fukuyama (2013). What is Governance. Working Paper. Center for Global Development. www.cgdev.org

Malaysia Administrative Modernisation and Management Planning Unit (2010). Pelan

Strategik MAMPU 2008-2012. Malaysia Administrative Modernisation and Management Planning Unit: Putrajaya, Malaysia.

Nor Fatimah Che Sulaiman. (2013). Innovative and human capital capacity towards Malaysia's economic development. In: 1st International Conference on Innovation and Sustainability (ICOIS 2013), 3-4 April 2013, Sunway Resort Hotel \& Spa Kuala Lumpur, Malaysia. (Unpublished).

Omar Osman (2013). "Mensinergi Ekosfera Untuk Kecemerlangan Universiti" Teks Perutusan Naib Canselor Universiti Sains Malaysia (USM), Thursday, 10 January 2013. Tenth Malaysia Plan. (2011-2015). Retrieved from:

http://onlineapps.epu.gov.my/rmke10/rmke10_bm.html 
